\title{
Growth and reproduction in captivity unveils remarkable life-history plasticity in the smallnose fanskate, Sympterygia bonapartii (Chondrichthyes: Rajiformes)
}

\author{
Julieta A. Jañez ${ }^{1}$, Fernando J. Meijide², Luis O. Lucifora ${ }^{3}$, \\ Carolina Abraham ${ }^{1}$ and Federico Argemi ${ }^{1}$
}

We analyzed growth and reproduction of captive-born smallnose fanskates Sympterygia bonapartii. Egg cases were obtained from oviposition of two females caught in the wild and held at Temaikèn Aquarium. Following hatching, growth was analyzed in 13 females and 21 males until sexual maturity. Pattern of oviposition activity and reproductive performance were evaluated in six of the captive-reared females. Four models were fitted to growth data, among which the logistic function was the one attaining the best fit. The highest growth rate for both sexes was recorded during the first year of life, whereas growth was significantly higher in females than in males during the second year. Size at first oviposition was $61.7 \pm 3.5 \mathrm{~cm}$ TL, similar to wild specimens. However, captive-reared females reached maturity before two years of age, i.e. much earlier than wild skates, implying a significant phenotypic plasticity in this species. The similarity in size at maturity and the difference in age at maturity between captive and wild specimens indicate that there is a decoupling of both parameters mediated through growth rates. Captive-born skates reproduced successfully and yielded viable offspring, indicating that the environment at Temaikèn Aquarium is suitable for $S$. bonapartii to attain its full life cycle.

Keywords: Arhynchobatidae, Captive breeding, Growth to maturity, Reproductive performance, Skates.

Analizamos el crecimiento y la reproducción de ejemplares de raya marmorada, Sympterygia bonapartii nacidas en cautiverio. Se obtuvieron ovicápsulas a partir de la oviposición de dos hembras capturadas en la naturaleza y mantenidas en el Acuario Temaikèn. Posteriormente a la eclosión, se analizó el crecimiento en 13 hembras y 21 machos hasta la madurez sexual. Se evaluó el patrón de oviposición y la performance reproductiva en seis de las hembras criadas en cautiverio. Se ajustaron cuatro modelos a los datos de crecimiento, entre los cuales la función logística fue la que logró el mejor ajuste. Para ambos sexos, la mayor tasa de crecimiento se registró durante el primer año de vida. Durante el segundo año, la tasa de crecimiento fue significativamente mayor en hembras que en machos. La talla de primera oviposición fue de $61,7 \pm 3,5 \mathrm{~cm}$ LT, similar a la estimada en rayas silvestres. Sin embargo, las hembras criadas en cautiverio alcanzaron la madurez antes de los dos años de vida, es decir mucho antes que en el ambiente natural, lo que implica una plasticidad fenotípica significativa en esta especie. La similitud en la talla de madurez y la diferencia en la edad de madurez entre individuos cautivos y silvestres indican que hay un desacople de ambos parámetros mediado por la tasa de crecimiento. Los individuos nacidos en cautiverio se reprodujeron exitosamente y dejaron descendencia viable, lo que indica que el ambiente del Acuario Temaikèn es adecuado para que $S$. bonapartii complete su ciclo de vida.

Palabras clave: Arhynchobatidae, Crecimiento, Cría en cautiverio, Performance reproductiva, Rayas.

\section{Introduction}

The life history of elasmobranch fishes can be characterized as being typical of equilibrium strategists (Frisk et al., 2001; Charnov, 2002). They depend on a relatively stable environment and high offspring survival, producing young that are relatively large and precocious. Juveniles emerge resembling miniature adults and do not undergo developmental stages in the open environment (Winemiller, Rose, 1992; Luer et al., 2007), foregoing the high mortality rates that many fishes experience (Wourms et al., 1988; Pratt, Casey, 1990). Although copulation and internal fertilization

\footnotetext{
${ }^{1}$ Fundación Temaikèn, Acuario, Ruta Provincial 25 Km. 0.700 (1625) Escobar, Buenos Aires, Argentina. (JAJ) jjanez@temaiken.org.ar, Ohttps://orcid.org/0000-0001-8021-1227 (corresponding author), (CA) caro.abraham.1978@gmail.com, (FA) fargemi@temaiken.org.ar ${ }^{2}$ DBBE, IBBEA-CONICET, Facultad de Ciencias Exactas y Naturales, Universidad de Buenos Aires. Int. Güiraldes 2160 (C1428EGA) Ciudad Autónoma de Buenos Aires, Argentina. fmeiji@gmail.com

${ }^{3}$ Instituto de Biología Subtropical - Iguazú, Universidad Nacional de Misiones, CONICET, Casilla de Correo 9 (N3370AVQ) Puerto Iguazú, Misiones, Argentina. luis.lucifora@conicet.gov.ar
} 
are common to all elasmobranchs, numerous variations in strategies of embryonic nutrition and development exist, ranging from oviparity to viviparity. Oviparity is found in all species of five families of sharks (Heterodontidae, Parascylliidae, Hemiscylliidae, Stegostomatidae, Scyliorhinidae) (Wyffels, 2009), and is also found in at least one species of Proscylliidae (Ebert et al., 2013). Among batoids, oviparity is restricted to the skates (Order Rajiformes) where it occurs throughout all extant families (Wyffels, 2009). In oviparous species, an egg case that encloses the embryo during the long developmental periods provides protection and serves as a modulating mechanism, regulating the embryos contact with the outside environment (Berestovskii, 1994; Hamlett et al., 2005). Physical changes to the egg case and internal chamber are triggered by the embryo, providing the critical physical requirements necessary for successful growth and development (Koob, Cox, 1990; Berestovskii, 1994; Hamlett, Koob, 1999; Wyffels, 2009).

Elasmobranchs in general have slow growth rate, late age at first maturity, low fecundity and relatively low natural mortality (Dulvy, Forrest, 2010). These characteristics - especially the late maturity - make them particularly vulnerable to over-exploitation by fisheries (Hutchings et al., 2012). However, and although sharing these main features, batoid species exhibit a large variation in their life-history parameters and therefore show differences in their plasticity to changes in the environment (Serra-Pereira et al., 2005).

Age, growth, and reproduction parameters are crucial for accurate stock assessment and evaluation of elasmobranch population dynamics (Cailliet et al., 1986; Cailliet, Goldman, 2004). Growth rate, age and size at maturity, and fecundity are central to define management and conservation strategies at population level (Dulvy, Forrest, 2010). Ideally, these parameters are estimated from examination of wild specimens. However, even though growth in captive specimens may differ from that of wild conspecifics, studies of growth in laboratory and aquarium specimens have provided valuable life history information, particularly when none is otherwise available (Cailliet, Goldman, 2004; Mohan et al., 2004; Henningsen, Leaf, 2010). Among skates, which commonly have extended egg-laying periods (Kyne, Simpfendorfer, 2010), studies using captive specimens have produced reliable estimates of fecundity (e.g. Jañez, Sueiro, 2009; Palm et al., 2011; Mabragaña et al., 2015). These estimates commonly are used complementarily with parameters obtained from wild specimens in assessments of both populations and species (e.g. Walker, Hislop, 1998; Barnett et al., 2013).

Another possible use of studies performed in captivity is to evaluate the phenotypic plasticity of life history parameters. Life-history plasticity is at the core of density-dependent population regulation, by which individuals in a population adjust growth rate, fecundity, age or size at maturity as a response to a change in density of the population (Rose et al., 2001). Without enough plasticity in those parameters, density-dependent regulation is possible only through genetic adaptation (Dieckmann, Heino, 2007). Studies in captiv- ity to evaluate the potential of phenotypic plasticity in population regulation have been conducted in teleost fishes $(e . g$. Hutchings et al., 2007), but not on elasmobranchs. Densitydependent changes in life-history parameters are difficult to detect in wild elasmobranchs, since the usually long lifespan of elasmobranchs dampens the magnitude of such changes (Natanson et al., 2014). Therefore, assessment of plasticity in life-history parameters of exploited elasmobranchs under captive, controlled conditions may shed some light on the potential extent of such changes and their effects on population regulation.

The skate genus Sympterygia Müller \& Henle, 1837 comprises four arhynchobatid species endemic to the temperate Atlantic and Pacific waters of South America. The smallnose fanskate, Sympterygia bonapartii Müller \& Henle, 1841, occurs regularly from off Santos, Brazil $\left(24^{\circ} \mathrm{S}\right.$, Menni, Stehmann, 2000) to Santa Cruz Province, Argentina (49 ${ }^{\circ} \mathrm{S}$, Cousseau et al., 2007), from the intertidal to 100 $\mathrm{m}$ deep (Menni, Stehmann, 2000). The reproductive biology of $S$. bonapartii has been extensively studied and parameters such as size at maturity and fecundity are well known (Mabragaña et al., 2002; Oddone, Velasco, 2004; Oddone, Vooren, 2008; Galíndez et al., 2010; Díaz-Andrade et al., 2013; Basallo, Oddone, 2014; Moya et al., 2015; Estalles et al., 2017). Recently, growth parameters and age at maturity of this species in the wild have been estimated (Hozbor, Massa, 2015). Since 1994, S. bonapartii has become increasingly important in southwest Atlantic fisheries as one of the most abundant and fished skates along the Argentine coast (Massa et al., 2004; Cedrola et al., 2005; Tamini et al., 2006; Estalles et al., 2011). Regarding its conservation status, this species is under the "Data Deficient" category of the IUCN Red List (Massa, Lamilla, 2004).

Due to a variety of reasons, some elasmobranchs are among the most difficult species to maintain in captivity. Compared to most teleost fishes, elasmobranchs require larger and more specialized facilities, as well as more careful handling. In addition, they have greater nutritional requirements and are more susceptible to suffer physiological stress responses (Smith et al., 2004). However, the advancements in husbandry techniques and design of large aquarium systems have allowed public aquarium staff and scientific researchers to collect, transport and maintain elasmobranchs in captivity (Gruber, Keyes, 1981; Cliff, Thurman, 1984; Andrews, Jones, 1990; Murru, 1990; Uchida et al., 1990; Smith, 1992; Smith et al., 2004). Likewise, captive breeding of elasmobranchs has increased during recent decades. Henningsen et al. (2004) described successful reproduction of 99 elasmobranchs species in captivity, 11 species belonging to the order Rajiformes. The goal of most aquariums, and the final test of successful aquarium husbandry, is to provide an environment where a species can attain its full life span and reproduce successfully, engendering successive captive generations (Castro, 2013). Hitherto, to our knowledge, reproduction of elasmobranchs born and bred to sexual maturity in captivity has been achieved only in very few species, such 
as the freshwater stingray Potamotrygon motoro (Müller \& Henle, 1841) (Thorson et al., 1983), the whitetip reef shark Triaenodon obesus (Rüppell, 1837) (Uchida et al., 1990), the southern stingray Hypanus americanus (Hildebrand \& Schroeder, 1928) (Henningsen, Leaf, 2010) and the sand tiger shark Carcharias taurus Rafinesque, 1810 (Willson, Smith, 2017). In previous research at Temaikèn Aquarium, the oviposition rate of wild-caught female $S$. bonapartii, as well as the incubation period and size of neonates at hatching were assessed (Jañez, Sueiro, 2007, 2009). Here, we report on the complete life cycle of $S$. bonapartii in captivity, yielding viable offspring from a generation reared under controlled conditions. As a first objective of this study, we determined the growth model that provided the best fit for the length-at-age data in captive-born specimens, and compared it with growth estimates from wild specimens to assess the extent of plasticity in growth, and age and size at maturity. The second goal of this study was to assess the reproductive capability of captive-reared $S$. bonapartii at Temaikèn Aquarium.

\section{Material and Methods}

Wild animals. Two mature female $S$. bonapartii (female 1: total body length (TL) $65 \mathrm{~cm}$, disc width (DW) $42 \mathrm{~cm}$; female 2: TL $65 \mathrm{~cm}, \mathrm{DW} 47 \mathrm{~cm}$ ) and eight males (mean $\pm \mathrm{SD}$ TL: $60.2 \pm 3.3 \mathrm{~cm}$, mean \pm SD DW: $40.2 \pm 1.5 \mathrm{~cm})$ were caught by demersal otter trawls off Mar del Plata, Argentina $\left(38^{\circ} 09 \mathrm{~S} ; 5^{\circ} 33^{\prime} \mathrm{W}\right)$ between July and December 2002. Following capture, the skates were transported to Temaikèn Aquarium, Escobar, Buenos Aires, where they were housed in a $1000 \mathrm{~m}^{3}$ tank, provided with a recirculating natural seawater system equipped with both biological and mechanical filtration, and ozone disinfection. They were kept at a salinity of 35-37\%, temperature between $14.4^{\circ} \mathrm{C}$ and $18.2{ }^{\circ} \mathrm{C}$ and a $12: 12 \mathrm{~h}$ photoperiod. Water quality parameters were $\mathrm{NH}_{4}^{+}<0.05 \mathrm{mg} \mathrm{l}^{-1}, \mathrm{NO}_{2}^{-}<0.05 \mathrm{mg} \mathrm{l}^{-1}, \mathrm{NO}_{3}=50 \mathrm{mg} \mathrm{l}^{-1}$, dissolved $\mathrm{O}_{2}=8 \mathrm{mg} \mathrm{l}^{-1}$. The skates were fed daily to satiation with a diet including fresh fish (Percophis brasiliensis Quoy \& Gaimard, 1825, Odontesthes incisa (Jenyns, 1841), Engraulis anchoita Hubbs \& Marini, 1935), squid (Illex argentinus (Castellanos, 1960)) and shrimps (Palaemonetes sp.).

In August 2005, each female was housed individually in two separate $15 \mathrm{~m}^{3}$ circular tanks along with one or two males, under the same water conditions as described above. In these tanks, regular egg case deposition was recorded throughout the year. Egg cases were collected during a tenmonth period, from August 2005 to June 2006. Oviposition was not monitored for the females from the time of collection (2002) until July 2005. Shortly after deposition, egg cases were transferred and maintained in incubation boxes $(0.8 \times 0.5 \times 0.4 \mathrm{~m})$ placed in a tank which was subjected to the same conditions described as for maintaining adults. Incubation boxes had perforations that enabled continuous water flow from the tank's recirculation system. Egg cases were identified with a plastic tag attached with a thin nylon thread to one of the posterior horns. The date of laying was written on each tag so that ages of embryos could be determined at any time during the developmental process. The viability of the embryos within the cases was checked daily under transmitted lighting provided by a submersible flashlight.

Growth to sexual maturity. A total of 34 S. bonapartii specimens (13 females and 21 males) born at Temaikèn Aquarium from December 2005 to June 2006 were maintained in two $15 \mathrm{~m}^{3}$ tanks using water quality and feeding conditions previously reported. The TL, DW and total weight (TW) were recorded monthly from birth until June 2009. In order to identify each specimen during the course of the study, skates were individually marked with coloured Visible Implant Elastomer (VIE) tags (Northwest Marine Technology Inc., USA). The elastomer was implanted following manufacturer's instructions, on the ventral side of the pectoral fin. The VIE was injected as a liquid that cured into a pliable, bio-compatible solid. This tag could be externally visualized under UV lighting throughout growth.

Four growth models are most commonly used in description of age and growth of elasmobranchs: the von Bertalanffy growth model (VBGM), the two-parameter VBGM, the Robertson (Logistic) model, and the Gompertz model (Cailliet et al., 2006). For this reason, multiple growth models were fitted to length-at-age-data of individual skates, as recommended by Cailliet et al. (2006). These models included two versions (VB1 and VB2) of the von Bertalanffy model. VB1 is the original formulation of the von Bertalanffy model, which includes size at birth $\left(L_{0}\right)$ as one of its parameters. It has the form:

$$
L_{t}=L_{\infty}-\left(L_{\infty}-L_{0}\right) e^{-k t}
$$

where $L_{\mathrm{t}}$ is total length at age $t, L_{\infty}$ is asymptotic length, $L_{0}$ is size at birth, $k$ is a parameter of the model proportional to growth rate, and $t$ is age.

VB2 is a well-known reparameterization of VB1, and is the most common growth model employed to describe elasmobranch growth (Cailliet et al., 2006):

$$
L_{t}=L_{\infty}\left(1-e^{-k\left(t-t_{0}\right)}\right)
$$

with the same parameters as VB1, excepting $t_{0}$, which represents age at zero size. Although $t_{0}$ has been interpreted as gestation time in elasmobranchs, it produces unrealistic estimates of gestation time and does not have any particular biological meaning (Cailliet et al., 2006; Smart et al., 2016).

The other two growth functions that were fitted were the Gompertz and the Logistic models, which have the following forms:

$$
\text { Gompertz: } L_{t}=L_{\infty} e^{-e^{-k(t-T)}} \text {; }
$$

with the same parameters as VB1, excepting $T$ is time at inflection. 


$$
\text { Logistic: } L_{t}=L_{\infty} /\left(1+e^{-k(t-T)}\right) \text {; }
$$

with parameters as in Gompertz.

In all cases, separate growth curves were fitted to each sex. For VB1, $L_{0}$ was fixed as the mean size at hatching (females: $13.97 \mathrm{~cm} \mathrm{TL}$, males: $14.03 \mathrm{~cm} \mathrm{TL}$ ).

Since data were multiple measurements of total length on the same individuals at different times (i.e. a longitudinal design), a mixed-effects modeling approach had to be employed to avoid pseudoreplication. Therefore, individual identity was included as a random effect in a nonlinear estimation of each growth function (Pinheiro, Bates, 2000). Model fitting was implemented in package nlme (Pinheiro et al., 2014) of $\mathrm{R}$ version 3.1.1 ( $\mathrm{R}$ Core Team 2014). The best fitting model was chosen as that with the lowest Akaike Information Criterion (AIC). Parameters of the best model were compared between sexes by means of the conditional t-test, as indicated for mixed-effects models (Pinheiro, Bates, 2000).

The absolute growth rate was determined for the first, second and third year of life in each sex. Data were analyzed by means of Repeated Measures Analysis of Variance, followed by Tukey's post hoc comparisons.

Reproductive performance. Observation of the first deposition of an embryonated egg case by captive-born females was indicative that sexual maturity had been attained in skates of both sexes. From that moment, six of the females were individually isolated in separate $15 \mathrm{~m}^{3}$ circular tanks under the same water recirculation system. Two or three captiveborn males were housed with each female. No precautions were taken to avoid breeding between sibling skates. Egg case oviposition was monitored in these tanks over a period of 289-366 days. Each female was assessed regarding the presence of intervals of regular laying activity and resting periods, or a relatively constant rate of laying. In addition, fecundity (number of egg cases laid), oviposition rate (number of egg cases laid per day during the oviposition period), fertilization rate ( $\%$ of embryonated egg cases) and hatching rate ( $\%$ of hatched juveniles) were determined for each female. Spearman's correlation coefficient was used to study the correlation between female size or weight and the oviposition rate. In addition, the mean size (length and width) of egg cases, the average duration of the incubation period, and the mean size (TL) of skates upon hatching were recorded. Size measurements were performed using a caliper graduated to the nearest $\mathrm{mm}$. For egg case measurement, the length was recorded as the distance between the anterior and posterior ends, excluding the horns, and width was recorded as the maximum distance between the lateral margins of the case. Nomenclature of egg case anatomy was based on Mabragaña et al. (2011). Reproductive parameters recorded for captive-born females were compared with those previously recorded for the wild-caught progenitor skates by means of Mann-Whitney U test. Statistical significance was set at $\mathrm{p}<0.05$.
Fundación Temaikèn is a member of ALPZA (Asociación Latinoamericana de Parques Zoológicos y Acuarios), WAZA (World Association of Zoos and Aquariums) and AZA (Association of Zoos and Aquariums), and thus complies with their standards on animal welfare. Protocols used in this study have undergone an ethical review process by Temaikèn Animal Care and Use Committee.

\section{Results}

Growth to sexual maturity. The highest growth rate of captive-born skates was recorded during the first year of life (p $=0.0001)$, with no differences between sexes $(p=0.2871)$. In contrast, during the second year of life, the absolute growth rate was significantly higher in females than in males $(\mathrm{p}=$ 0.0001 ) (Tab. 1). As a result, females were larger than males upon reaching maturity $(\mathrm{p}=0.0002)$ (Fig. 1). Oviposition was observed first for captive-bred females when they were $22 \pm 1.7$ months old (mean $\pm \mathrm{SD}$ ), $61.7 \pm 3.5 \mathrm{~cm}$ TL (mean $\pm \mathrm{SD}$ ) and $2121.7 \pm 379.6 \mathrm{~g}$ TW (mean $\pm \mathrm{SD}$ ). During the third year of life, growth curves reached a plateau (Fig. 1) and the increase in length was slightly over $1 \mathrm{~cm}$ for both sexes (Tab. 1). The maximum sizes recorded for females and males were $64.5 \pm 3.3 \mathrm{~cm} \mathrm{TL}$ (mean $\pm \mathrm{SD}$ ) and $58.2 \pm 2.7 \mathrm{~cm}$ $\mathrm{TL}$ (mean $\pm \mathrm{SD}$ ), respectively; whereas the maximum ages attained by females and males were $3.5 \pm 1.4$ years (mean \pm SD) (range: $2.0-6.8$ years) and $5.2 \pm 1.4$ years (mean \pm SD) (range: $3.5-8.5$ years), respectively.

In both sexes, the growth model with the best fit was the Logistic model (Fig. 1). Parameters and Akaike Information Criterion of each model for each sex are shown in Tab. 2. All three parameters of the Logistic model differed significantly between sexes $\left(L_{\infty}: t=-20.43, \mathrm{p}<0.0001 ; k: t=2.15, \mathrm{p}=\right.$ $0.0314 ; T: t=-3.44, \mathrm{p}=0.0006$ ).

Tab. 1. Annual absolute growth of Sympterygia bonapartii born at Temaikèn Aquarium (Argentina). Values expressed as mean \pm standard deviation. Different letters indicate significant difference $(\mathrm{p}<0.05)$.

\begin{tabular}{|c|c|c|c|}
\hline \multicolumn{4}{|c|}{ Absolute growth rate $\left(\mathrm{cm}\right.$ year $\left.{ }^{-1}\right)$} \\
\hline & 1st year & 2nd year & 3rd year \\
\hline Females $(n=13)$ & $27.20 \pm 2.36$ (a) & $20.12 \pm 4.28(b)$ & $1.28 \pm 0.93(\mathrm{~d})$ \\
\hline Males $(n=21)$ & $25.43 \pm 3.44(\mathrm{a})$ & $16.14 \pm 3.49(\mathrm{c})$ & $1.18 \pm 0.81(\mathrm{~d})$ \\
\hline
\end{tabular}

Reproductive performance. From August 2007 to April 2008, reproduction was recorded for the first generation $S$. bonapartii born at Temaikèn Aquarium. Pre-copulatory behaviour was observed on five occasions during this eightmonth period. During pre-copulation, the pair of skates used to lie motionless on the bottom of the tank falling on their backs, with the male biting and holding the female by the pectoral fin. Copulation, namely insertion of male's clasper into the female's cloaca, was recorded only once and was found to last just a few seconds. The size of captive-born first generation males yielding embryonated eggs for female 


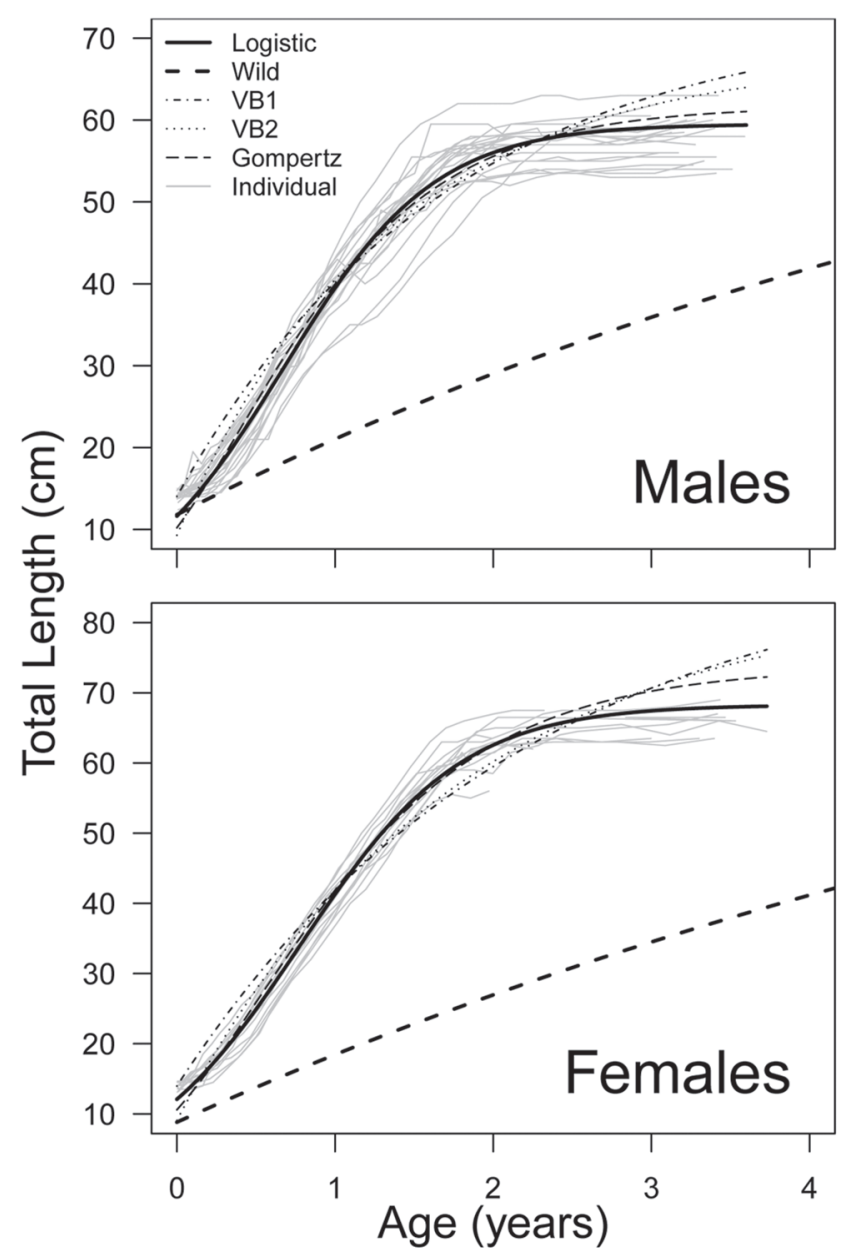

Fig. 1. Growth of Sympterygia bonapartii born at Temaikèn Aquarium (Argentina). Individual growth trajectories $(n=21$ males and 13 females) are shown as grey lines. The Logistic model (bold black line) is the one with the best fit to the data (lowest Akaike Information Criterion). Other models fitted are von Bertalanffy with size at birth (VB1), von Bertalanffy with $t_{0}$ parameter (VB2), and Gompertz models. The best model describing the growth of wild $S$. bonapartii (bold dashed line) from off northern Argentina, as estimated by Hozbor and Massa (2015), has the same form as VB1.

tankmates was $54.0 \pm 2.4 \mathrm{~cm}$ TL (mean \pm SD), $37.2 \pm 1.4$ $\mathrm{cm} \mathrm{DW}($ mean $\pm \mathrm{SD})$ and $1207.8 \pm 125.9 \mathrm{~g}$ TW (mean \pm SD). At the time of egg case deposition, the female settled on the bottom of the tank, contracted the posterior lobes of the pelvic fins ventrally and shook her pelvic region from side to side to lay the egg case. The hatching terminus with the posterior filiform horns was the portion of the egg case that initially protruded from the cloaca during oviposition. After releasing the egg case, the skate swam away. The posterior horns of the cases were longer than the anterior ones and possessed sticky mucous tendrils that aided in anchoring the egg case to its surrounding substrate. Since tanks were devoid of substrates, skates deposited their egg cases directly on the bottom. Egg cases were laid in pairs. The time interval between deposition of cases from a same pair ranged from less than an hour to a few hours. The size of egg cases was $76.0 \pm 2.1 \mathrm{~mm}$ long (mean $\pm \mathrm{SD}$ ) and $43.4 \pm$ $1.0 \mathrm{~mm}$ wide (mean $\pm \mathrm{SD}$ ). The duration of the incubation period was $135 \pm 6$ days (mean $\pm \mathrm{SD}$ ), and the size of neonate skates was $13.2 \pm 0.2 \mathrm{~cm}$ TL (mean $\pm \mathrm{SD}$ ). These second generation parameters did not differ significantly from those recorded for the first generation from wild-caught skates ( $\mathrm{p}$ $>0.0714$ ). Fig. 2 shows egg cases of $S$. bonapartii and a recently hatched skate inside an incubation box.

Tab. 2. Parameters of models describing the growth for both sexes of Sympterygia bonapartii born at Temaikèn Aquarium (Argentina). VB1 is the von Bertalanffy model parameterized in its original form, i.e. with $L_{0}=$ size at birth, which was fixed as the mean total length at birth. VB2 is the form of the von Bertalanffy model most commonly fitted to elasmobranch growth, i.e. with parameter $t_{0}$. $L_{\infty}$ is asymptotic size, $k$ is a parameter related to growth rate, and $T$ (for Gompertz and Logistic models) is age at which the inflection point occurs. AIC is Akaike Information Criterion.

\begin{tabular}{lcccc}
\hline \multicolumn{1}{c}{ Model } & AIC & $\mathrm{L}_{\infty}$ & $\mathrm{k}$ & $\mathrm{L}_{0} / \mathrm{t}_{0} / \mathrm{T}$ \\
\hline Females & & & & \\
\hdashline VB1 & 1830.0 & 90.02 & 0.46 & 13.97 (fixed) \\
VB2 & 1685.4 & 84.38 & 0.57 & 0.20 \\
Gompertz & 1413.3 & 73.68 & 1.23 & 0.54 \\
Logistic & 1150.2 & 68.30 & 1.96 & 0.78 \\
\hdashline Males & & & & \\
\hdashline VB1 & 2948.8 & 72.99 & 0.59 & 14.03 (fixed) \\
VB2 & 2756.7 & 67.72 & 0.76 & 0.19 \\
Gompertz & 2373.3 & 61.70 & 1.42 & 0.41 \\
Logistic & 2026.1 & 59.51 & 2.09 & 0.67 \\
\hline
\end{tabular}

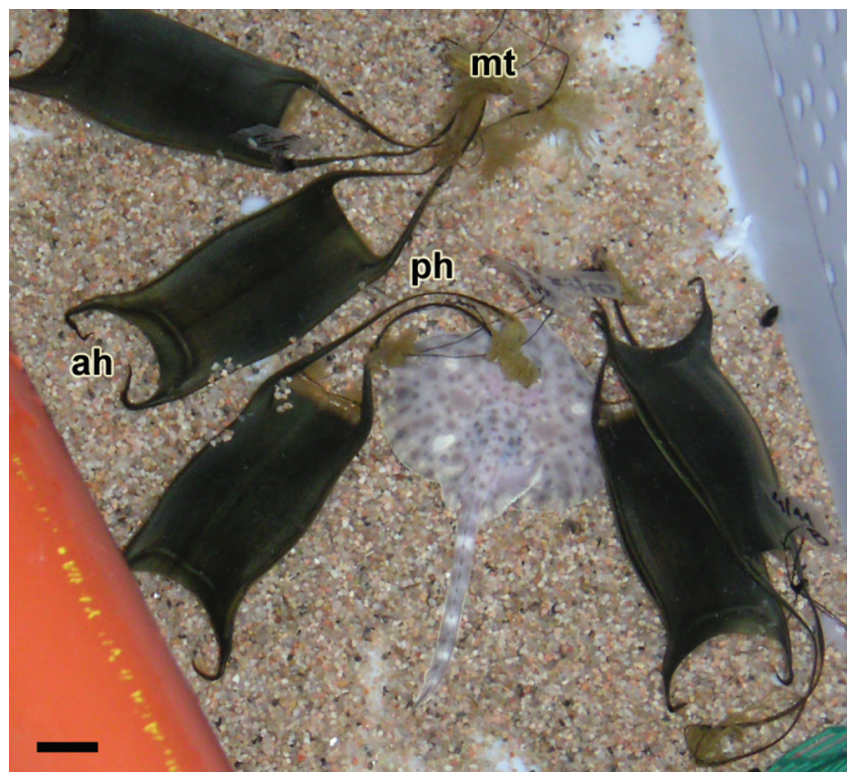

Fig. 2. Egg cases and neonate of Sympterygia bonapartii born at Temaikèn Aquarium (Argentina). ah, anterior horns; $\mathrm{mt}$, mucous tendrils; ph, posterior horns. Scale bar: $20 \mathrm{~mm}$. 
Table 3 provides data corresponding to egg case laying activity and values of parameters of reproductive performance recorded for six of the captive-born females. Within the analyzed period, intervals of regular laying activity that alternated with a resting period were observed for four of the females, whereas the other two females exhibited continuous oviposition. The duration of the resting period was variable among females, ranging from 151 to 190 days. The interval between laying of successive egg case pairs during the oviposition period ranged from 2 to 28 days (mean \pm SD: $5.3 \pm 1.9$ days). The oviposition rate ranged from 0.25 to 0.56 egg cases laid per day (or one egg case every 4 to 2 days, respectively) and was positively correlated with both female size (Spearman's correlation coefficient $=0.9429, \mathrm{p}$ $=0.0048)$ and weight (Spearman's correlation coefficient $=$ $0.8286, \mathrm{p}=0.0416$ ). The fertilization rate was above $77 \%$ in all females, whereas the hatching rate ranged from 45 to $71 \%$. Comparisons of reproductive performance recorded for the two wild-caught progenitor skates with first generation females revealed no statistical differences $(p=0.6429$ for oviposition rate, $\mathrm{p}=0.0714$ for fertilization rate and $\mathrm{p}=$ 0.6429 for hatching rate).

Tab. 3. Reproductive performance of Sympterygia bonapartii born at Temaikèn Aquarium (Argentina). TL: total length; DW: disc width; TW: total weight; LP: period of egg-case laying activity; RP: resting period (no oviposition); F: fecundity (\# eggcases laid during LP time period); E: \# empty egg-cases; TI: time interval between successive laying of egg-case pairs during LP time period (mean $\pm \mathrm{SD}$ and range in parenthesis); OR: oviposition rate (\# egg-cases per day, i.e. F/LP), FR: fertilization rate (\% of embryonated egg-cases); HR: hatching rate ( $\%$ of hatched juvenile skates). C: captive-born skate, W: wild-caught skate. The period of data recording ranged from 289 days (specimen C1) to 366 days (specimen C6). TL, DW and TW are expressed as the average of values registered at the beginning and end of the data recording period.*Data corresponding to wild-caught specimens, taken from Jañez and Sueiro (2009). A: absence of resting period. ND: not determined.

\begin{tabular}{|c|c|c|c|c|c|c|c|c|c|c|c|c|}
\hline Specimen & $\begin{array}{l}\mathrm{TL} \\
(\mathrm{cm})\end{array}$ & $\begin{array}{l}\text { DW } \\
(\mathrm{cm})\end{array}$ & $\begin{array}{l}\mathrm{TW} \\
(\mathrm{g})\end{array}$ & $\begin{array}{l}\text { Date of } 1^{\text {st }} \\
\text { oviposition }\end{array}$ & $\begin{array}{c}\text { LP } \\
\text { (days) }\end{array}$ & $\begin{array}{c}\mathrm{RP} \\
\text { (days) }\end{array}$ & $\mathrm{F}$ & E & $\begin{array}{c}\text { TI } \\
\text { (days) }\end{array}$ & OR & FR & HR \\
\hline $\mathrm{C} 1$ & 66.3 & 45.3 & 2687.8 & $12 / 17 / 2007$ & 110 & 179 & 62 & 9 & $3.8 \pm 1.3(2-6)$ & 0.56 & 85.48 & 58.06 \\
\hline $\mathrm{C} 3$ & 61.8 & 42.8 & 2099.7 & $10 / 18 / 2007$ & 158 & 190 & 56 & 1 & $6.1 \pm 3.3(3-20)$ & 0.35 & 94.64 & 44.64 \\
\hline $\mathrm{C} 4$ & 60.5 & 42.5 & 2071.2 & $10 / 10 / 2007$ & 157 & 162 & 40 & 8 & $8.7 \pm 5.7(4-28)$ & 0.25 & 77.50 & 55.00 \\
\hline Mean \pm SD & $62.6 \pm 2.0$ & $43.5 \pm 1.3$ & $2227.2 \pm 235.9$ & -- & $227 \pm 111$ & --- & $98 \pm 59$ & $6 \pm 4$ & $5.3 \pm 1.9$ & $0.42 \pm 0.11$ & $88.92 \pm 7.06$ & $54.95 \pm 9.22$ \\
\hline $\mathrm{W} 1 *$ & 65.0 & 42.0 & ND & $08 / 01 / 2005$ & 365 & A & 152 & 3 & $5.4 \pm 2.1(2-12)$ & 0.42 & 98.03 & 51.32 \\
\hline $\mathrm{W} 2 *$ & 65.0 & 47.0 & ND & $10 / 20 / 2005$ & 365 & A & 200 & 4 & $4.1 \pm 2.4(1-14)$ & 0.55 & 98.00 & 51.50 \\
\hline Mean \pm SD & $65.0 \pm 0.0$ & $44.5 \pm 3.5$ & --- & --- & $365 \pm 0$ & --- & $176 \pm 34$ & $4 \pm 1$ & $4.8 \pm 0.9$ & $0.48 \pm 0.09$ & $98.02 \pm 0.02$ & $51.41 \pm 0.13$ \\
\hline
\end{tabular}

\section{Discussion}

The husbandry conditions at Temaikèn Aquarium were adequate for $S$. bonapartii to complete its life cycle, from birth to reproduction. This was probably related to both the similar conditions of the enclosure to the natural habitat from where specimens were taken, and the eurytopic nature of the species. The temperature of the skate habitat at Temaikèn Aquarium was within the range of sea water temperature off north Argentina (8.2-23 ${ }^{\circ} \mathrm{C}$; Lucas et al., 2005). Salinity was slightly higher than the range found off north Argentina (20-34.1; Lucas et al., 2005), but $S$. bonapartii is able to live in a wide salinity range, even within estuaries (Mabragaña et al., 2002). In addition, $S$. bonapartii inhabits a wide latitudinal range along the east coast of South America, from south Brazilian $\left(\sim 24^{\circ} \mathrm{S}\right)$ to central Patagonian $\left(\sim 50^{\circ} \mathrm{S}\right)$ waters (Menni, Stehmann, 2000), which indicates that the species can adapt to oceanographic regimes ranging from subtropical to cold-temperate.

Husbandry conditions of reduced temperature fluctuations and high food availability were likely to be responsi- ble for the high growth rates observed, as reported for other elasmobranchs (Smith et al., 2004). Temperature is positively related to growth rate in fishes (Gislason et al., 2010; Sibly et al., 2015; Lorenzen, 2016), although it may have a negative effect if elevated beyond optimal levels (see Neer et al., 2007). Temperatures under which $S$. bonapartii were kept at Temaikèn Aquarium $\left(14.4{ }^{\circ} \mathrm{C}-18.2{ }^{\circ} \mathrm{C}\right)$ were closer to the summer water temperatures off north Argentina than to temperatures experienced by this species during winter (approximately 7 to $10^{\circ} \mathrm{C}$ higher than winter mean sea-water temperature off north Argentina). This may have accelerated growth rates. In addition, captive skates may have had higher food availability and lower energetic demands than wild skates, thus accelerating growth.

Females born at Temaikèn Aquarium had a higher growth rate than males during the second year of life and attained a larger asymptotic size. In elasmobranchs, females commonly reach a larger maximum size than males (Klimley, 1987). Usually this difference in size leads the biggest sex to delay sexual maturity, a process known as sexual bimaturation (Stearns, 1992). In some species, individu- 
als of the biggest sex reduce bimaturation by having higher growth rates (Stamps, Krishnan, 1997). We hypothesize that the higher growth rate of female $S$. bonapartii during the second year is a life history strategy that reduces age at maturity, hence reducing sexual bimaturation.

Captive-born females reached maturity in less than two years, which is significantly less than the age at maturity estimated for wild specimens. The only estimate of age at maturity for wild $S$. bonapartii females is $8.5-8.7$ years (Hozbor, Massa, 2015), whereas age at maturity for females in captivity was 1.8 years (this study). This 6.8-year difference could be explained by an acceleration of growth in captivity due to optimal husbandry conditions (see above). Similarly, captive-born males reached maturity in two years, i.e. 7.2 years earlier than in the wild (Hozbor, Massa, 2015). Another factor contributing to age discrepancy between captive and wild specimens is the aging method used for wild specimens. While age of captive skates was known with precision, wild skates were aged by counting unvalidated growth band pairs in vertebral centra (Hozbor, Massa, 2015). This is a standard technique for aging elasmobranchs; however, recent work indicates that vertebral band pair counts may not be correlated to actual age in elasmobranchs (Natanson et al., 2018).

Contrary to age at maturity, size at maturity of $S$. bonapartii in captivity is approximately the same as in the wild. Here, female size at maturity was estimated to be $61.7 \mathrm{~cm}$ TL based on the records of first oviposition. Interestingly, this size is fairly coincident with that estimated for 1.8 year-old female skates by the Logistic model, which was the model attaining the best fit. Earlier work has estimated female size at maturity at $63.6-65.5 \mathrm{~cm}$ TL off Uruguay and north Argentina (Mabragaña et al., 2002; Oddone, Velasco, 2004), $59.9 \mathrm{~cm}$ TL in south Brazil (Basallo, Oddone, 2014) and $59.4 \mathrm{~cm}$ TL in San Matías Gulf, north Patagonia (Estalles et al., 2017). The average size of first generation captive-born males yielding embryonated eggs for female tankmates was $54.0 \mathrm{~cm} \mathrm{TL}$, which is within the range of estimates for male size at maturity in the wild (52.0-65.1 $\mathrm{cm}$ ) (Estalles et al., 2017). No difference in size at maturity between captive and wild individuals has been reported previously for batoids (Henningsen, Leaf, 2010). The similarity of captive and wild size at maturity and the differences in age at maturity indicate that there is a decoupling of both parameters mediated through growth rates. High growth rates (as observed in captivity) produce a quicker attainment of size at maturity, without increasing this size.

Life span in captivity was much reduced as compared to wild populations of $S$. bonapartii. Maximum ages for $S$. bonapartii, as determined by vertebral band pairs from wild specimens, were 14 and 11 years for females and males, respectively (Hozbor, Massa, 2015). In contrast, the maximum ages of captive-born specimens recorded during this study were 6.8 years (mean 3.5) and 8.5 years (mean 5.2) for females and males, respectively. In general, growth band pairs tend to underestimate actual age in elasmobranchs, especially among the oldest individuals (Harry, 2017). For this reason, the difference in longevity between captive and wild $S$. bonapartii is likely to be even higher than observed. It is unclear why longevity is reduced in captivity. One potential explanation may be the high growth rates that lead to fast sexual maturity of captive individuals, as senescence is accelerated as reproductive value decreases after sexual maturity (Stearns, 1992). In addition, it has been reported that females have higher longevity than males in the wild (Hozbor, Massa, 2015), whereas the opposite situation was unexpectedly recorded for captive-born specimens at Temaikèn Aquarium. One possible explanation for this difference is that females cannot avoid male's sexual harassment in a confined space, as coercive mating attempts have been suggested to influence female's long-term fitness in elasmobranchs (Uchida et al., 1990; Wearmouth et al., 2012).

In this study, $S$. bonapartii did not reach the maximum sizes recorded in the wild. Wild females attained 78.0-80.8 $\mathrm{cm}$ TL, and males 72.9-74.6 cm TL in Uruguay and north Argentina coastal waters (Mabragaña et al., 2002; Hozbor, Massa, 2015) whereas the maximum sizes recorded in San Matías Gulf, north Patagonia, were $74.2 \mathrm{~cm}$ and $68.7 \mathrm{~cm} \mathrm{TL}$ for females and males, respectively (Estalles et al., 2017). In contrast, the maximum sizes reached at Temaikèn Aquarium were 64.5 and $58.2 \mathrm{~cm}$ TL in females and males, respectively. This difference may have resulted from the shorter lives of captive specimens, as compared to wild skates. This also explains the small asymptotic sizes estimated by the Logistic model in both sexes.

An increase in growth rates and an earlier sexual maturity are the two changes associated to density-dependent compensatory regulation that have been observed in exploited sharks (e.g. Sminkey, Musick, 1995; Carlson, Baremore, 2003). Among skates, such changes have not been studied empirically, but a simulation analysis showed that the winter skate, Leucoraja ocellata (Mitchill, 1815), may be able to reduce its age at maturity from 14.5 to 10.5 years in response to exploitation (Frisk, 2010). These are the same changes that occur in captive $S$. bonapartii subjected to near-optimal conditions. At least in the northernmost part of its range, where temperatures are more similar to those of captive conditions, populations of $S$. bonapartii may counteract part of the fishing mortality through density-dependent compensatory changes in life-history parameters, enabled by phenotypic plasticity.

Taken together, our results indicate that significant plasticity in growth rate and age at maturity is present in $S$. bonapartii. Life history plasticity responding mainly to temperature and food availability has been experimentally demonstrated in marine teleost fish (Hutchings et al., 2007). This plasticity is essential for adaptive responses to environmental changes of both natural and anthropogenic origin (Lorenzen, 2016). In the case of S. bonapartii, such phenotypic plasticity may play a significant role in allowing this species to adapt to a broad environmental range, spanning 
from subtropical to cold-temperate waters, and to respond to the high fishing pressure to which it is subjected.

Maintenance of elasmobranchs in aquaria for successive generations has been attained in very few species. Successful breeding, as defined by Uchida et al. (1990), means that newborn or hatched pups are kept until they attain maturity and breed to produce their own offspring. S. bonapartii skates born at Temaikèn Aquarium reached maturity in 1.8 years and reproduced successfully. As far as we are aware of, our study provides the first report of second-generation captive birth for skates.

The oviposition behaviour of first generation captivereared females was coincident with that observed previously for wild-captured skates. Among captive-born females, four exhibited periods of regular laying activity that alternated with a resting period during which no oviposition was recorded. In contrast, the other two females exhibited continuous oviposition throughout the year, as previously recorded for wild-caught skates (Jañez, Sueiro, 2009). Seasonality in the breeding activity has been observed among elasmobranchs held in captivity, even when maintained at relatively constant temperature and photoperiod (Pratt et al., 1990; Henningsen et al., 2004). In the case of S. bonapartii, this seasonality differs from that recorded in the wild. Based on records of gonadosomatic index, oviducal gland index and diameter of ovarian follicles of mature females, the egg laying season in the wild was estimated to be SeptemberOctober through February (spring-summer) (Mabragaña et al., 2002; Estalles et al., 2017). In contrast, laying activity at Temaikèn Aquarium started earlier, from June-July through January. In addition, some of the females exhibited continuous oviposition throughout the year. These differences might arise from the fairly constant regime of temperature and photoperiod experienced by captive skates, different from wild skates.

The oviposition rate of captive-born $S$. bonapartii was positively correlated with both their size and weight. This suggests that bigger females have higher fecundity. The relationship between fecundity and body size is highly variable in skates, as fecundity has been found to be either positively related (e.g. Holden 1975; Perier et al., 2011) or not related whatsoever (e.g. Ebert et al., 2008; Serra-Pereira et al., 2011) to female body size. The percentage of unfertilized eggs was relatively low for all specimens. Unfertilized egg cases included both empty egg cases called wind eggs, and yolky egg cases in which the presence of a developing embryo inside could not be verified. Empty cases have been reported before for the thorny skate, Amblyraja radiata (Donovan, 1808), in which it has been suggested that the passage of the eggs through the ostium and into the egg case under formation within the oviducal gland could be delayed so that they cannot reach the egg case before it is fully formed and closed (Templeman, 1982). Hatching rates recorded for captive $S$. bonapartii were low as compared to fertilization rates. Failure in hatching might have been due to careless operational procedures in the aquarium (e.g. accidental ex- posure of egg cases to air during cleaning activities might have caused the death of the developing embryo inside). Although comparisons are hampered by the low number of analyzed specimens, no significant differences were observed between captive-born and wild-caught specimens regarding their reproductive performance. The size of the egg cases laid by captive-born females $(76.0 \pm 2.1 \mathrm{~mm}$ long and 43.4 $\pm 1.0 \mathrm{~mm}$ wide) was similar to that of the egg cases laid by their wild-caught mothers $(77.5 \pm 2.6 \mathrm{~mm}$ long and $45.4 \pm$ $2.2 \mathrm{~mm}$ wide; Jañez, Sueiro, 2009) and was also comparable to the size of egg cases sampled in the wild environment (76.8 $\pm 3.9 \mathrm{~mm}$ long and $48.4 \pm 0.7 \mathrm{~mm}$ wide; Mabragaña et al., 2002). The average duration of the incubation period recorded for egg cases laid by captive-born females was 135 days, coincidently with data recorded for egg cases laid by wild-caught skates (Jañez, Sueiro, 2007). The size of skates hatched from egg cases laid by captive born females (13.2 $\pm 0.2 \mathrm{~cm} \mathrm{TL}$ ) was slightly lower than that corresponding to egg case laying of wild-caught females $(14.0 \pm 0.6 \mathrm{~cm}$ TL; Jañez, Sueiro, 2007). In addition, survival rates within the second generation of skates were lower than among skates of the first generation. It is possible that the lower size and survival of F2 skates was caused by nutritional constrains experienced by their progenitors during captive life, inbreeding depression or other negative factors derived from captive conditions. In spite of this, many of the F2 skates survived and exhibited a comparable development to that of their F1 progenitors, although their growth was not quantitatively assessed. Further research is currently ongoing at Temaikèn Aquarium in order to improve the breeding programs developed for $S$. bonapartii and other elasmobranch species.

\section{Acknowledgments}

We thank the crew of the aquarium for assistance in the collection of egg cases and growth data recording. We also thank Fundación Temaikèn for supporting our work at Temaikèn Aquarium. We are grateful to two anonymous reviewers and to the editor, whose comments greatly improved this paper.

\section{References}

Andrews JC, Jones RT. A method for the transport of sharks for captivity. J Aqua Aquat Sci. 1990; 5:70-72.

Barnett LAK, Winton MV, Ainsley SM, Cailliet GM, Ebert DA. Comparative demography of skates: life-history correlates of productivity and implications for management. PLoS One. 2013; 8(5):e65000. Available from: https://doi.org/10.1371/ journal.pone. 0065000

Basallo A, Oddone MC. Reproductive biology of the skates Sympterygia acuta Garman, 1877 and S. bonapartii Müller \& Henle, 1841 (Chondrichthyes: Rajoidei) in south Brazil. Neotrop Ichthyol. 2014; 12(4):771-82.

Berestovskii EG. Reproductive biology of skates of the family Rajidae in the seas of the Far North. J Ichthyol. 1994; 34(6):26-37. 
Cailliet GM, Goldman KJ. Age determination and validation in chondrichthyan fishes. In: Carrier JC, Musick JA, Heithaus MR, editors. Biology of sharks and their relatives. Boca Raton: CRC Press; 2004. p.399-447.

Cailliet GM, Radtke RL, Welden BA. Elasmobranch age determination and verification: a review. In: Uyeno T, Arai R, Taniuchi T, Matsuura K, editors. Indo-Pacific fish biology: proccedings of the Second International Conference on IndoPacific Fishes. Tokyo: Ichthyological Society of Japan; 1986. p.345-360.

Cailliet GM, Smith WD, Mollet HF, Goldman KJ. Age and growth studies of chondrichthyan fishes: the need for consistency in terminology, verification, validation, and growth function fitting. Environ Biol Fish. 2006; 77(3-4):211-28.

Carlson JK, Baremore IE. Changes in biological parameters of Atlantic sharpnose shark Rhizoprionodon terraenovae in the Gulf of Mexico: evidence for density-dependent growth and maturity? Mar Freshwater Res. 2003; 54(3):227-34.

Castro JI. A primer on shark reproduction for aquarists. In: Sato $\mathrm{K}$, editor. Proceeding of the International Symposium Reproduction of Marine Life, Birth of New Life! Investigating the Mysteries of Reproduction. February 21-22, 2009. Tokyo: Okinawa Churashima Research Center. 2013; p.52-69.

Cedrola PV, González AM, Pettovello AD. Bycatch of skates (Elasmobranchii: Arhynchobatidae, Rajidae) in the Patagonian red shrimp fishery. Fish Res. 2005; 71(2):141-50.

Charnov EL. Reproductive effort, offspring size and benefit-cost ratios in the classification of life histories. Evol Ecol Res. 2002; 4(5):749-58.

Cliff G, Thurman GD. Pathological and physiological effects of stress during capture and transport in the juvenile dusky shark, Carcharhinus obscurus. Comp Biochem Physiol. 1984; 78(1):167-73.

Cousseau MB, Figueroa DE, Díaz de Astarloa JM, Mabragaña E, Lucifora LO. Rayas, chuchos y otros batoideos del Atlántico sudoccidental $\left(34^{\circ} \mathrm{S}-55^{\circ} \mathrm{S}\right)$. Mar del Plata: Instituto Nacional de Investigación y Desarrollo Pesquero; 2007.

Díaz-Andrade MC, Lopez-Cazorla A, Galíndez EJ. Histological remarks of the uterus of Sympterygia acuta (Garman, 1877) and Sympterygia bonapartii (Müller \& Henle, 1841) (Chondrichthyes; Rajidae). Int J Morphol. 2013; 31(3):864-72.

Dieckmann U, Heino M. Probabilistic maturation reaction norms: their history, strengths, and limitations. Mar Ecol Prog Ser. 2007; 335:253-69.

Dulvy NK, Forrest RE. Life histories, population dynamics, and extinction risks in chondrichthyans. In: Carrier JC, Musick JA, Heithaus MR, editors. Sharks and their relatives II: Biodiversity, adaptive physiology and conservation, Boca Raton: CRC Press; 2010. p.639-679.

Ebert DA, Fowler S, Compagno L. Sharks of the world: a fully illustrated guide. Plymouth: Wild Nature Press; 2013.

Ebert DA, Smith WD, Cailliet GM. Reproductive biology of two commercially exploited skates, Raja binoculata and $R$. rhina, in the western Gulf of Alaska. Fish Res. 2008; 94(1):48-57.

Estalles ML, Coller NM, Perier MR, Di Giácomo EE. Skates in the demersal trawl fishery of San Matías Gulf, Patagonia: species composition, relative abundance and maturity stages. Aquat Living Resour. 2011; 24(2):193-99.

Estalles ML, Perier MR, Di Giácomo EE. Reproductive biology of Sympterygia bonapartii (Chondrichthyes: Rajiformes: Arhynchobatidae) in San Matías Gulf, Patagonia, Argentina. Neotrop Ichthyol. 2017; 15(1):e160022.

Frisk MG. Life history strategies of batoids. In: Carrier JC, Musick JA, Heithaus MR, editors. Sharks and their relatives II: Biodiversity, adaptive physiology and conservation, Boca Raton: CRC Press; 2010. p.283-316.

Frisk MG, Miller TJ, Fogarty MJ. Estimation and analysis of biological parameters in elasmobranch fishes: A comparative life history study. Can J Fish Aquat Sci. 2001; 58(5):969-81.

Galíndez EJ, Díaz-Andrade MC, Avaca MS, Estecondo S. Morphological study of the oviductal gland in the Smallnose fanskate Sympterygia bonapartii (Müller and Henle, 1841) (Chondrichthyes, Rajidae). Braz J Biol. 2010; 70(2):325-33.

Gislason H, Daan N, Rice JC, Pope JG. Size, growth, temperature and the natural mortality of marine fish. Fish Fish. 2010; 11(2):149-58.

Gruber SH, Keyes RA. Keeping sharks for research. In: Hawkins AD, editor. Aquarium systems. New York: Academic Press; 1981. p.373-402.

Hamlett WC, Koob TJ. Female reproductive system. In: Hamlet WC, editor. Sharks, skates and rays: the biology of elasmobranch fishes. Baltimore: The Johns Hopkins University Press; 1999. p.398-443.

Hamlett WC, Knigth D P, Pereira FTV, Steele J, Sever M. Oviducal glands in condrichthyans. In: Hamlett, WC editor. Reproductive biology and phylogeny of chondrichthyes: sharks, batoid and chimaeras. Enfield: Science Publishers Inc.; 2005. p.301-336.

Harry AV. Evidence for systemic age underestimation in shark and ray ageing studies. Fish Fish. 2017; 19(2):185-200.

Henningsen AD, Leaf RT. Observations on the captive biology of the southern stingray. Trans Am Fish Soc. 2010; 139(3):783-91.

Henningsen AD, Smale MJ, Gordon I, Garner R, Marin-Osorno $\mathrm{R}$, Kinnunen N. Captive breeding and sexual conflict in elasmobranches. In: Smith M, Warmolts D, Thoney D, Hueter $\mathrm{R}$, editors. The elasmobranch husbandry manual: captive care of sharks, rays and their relatives. Columbus: Ohio Biological Survey Inc.; 2004. p.237-248.

Holden MJ. The fecundity of Raja clavata in British waters. ICES J Mar Sci. 1975; 36(2):110-18.

Hozbor NM, Massa AM. Estimación de los parámetros de crecimiento de Sympterygia bonapartii (Rajidae). Rev Inv Des Pesq. 2015; 27:71-82.

Hutchings JA, Myers RA, García VA, Lucifora LO, Kuparinen A. Life-history correlates of extinction risk and recovery potential. Ecol Appl. 2012; 22(4):1061-67.

Hutchings JA, Swain DP, Rowe S, Eddington JD, Puvanendran V, Brown JA. Genetic variation in life-history reaction norms in a marine fish. Proc R Soc B. 2007; 274(1619):1693-99.

Jañez JA, Sueiro MC. Size at hatching and incubation period of Sympterygia bonapartii (Müller \& Henle, 1841) (Chondrichthyes, Rajidae) bred in captivity at the Temaiken Aquarium. J Fish Biol. 2007; 70(2):648-50. 
Jañez JA, Sueiro MC. Oviposition rate of the fanskate Sympterygia bonapartii (Elasmobranchii, Rajidae) (Müller \& Henle, 1841) held in captivity. Pan-Am J Aquat Sci. 2009; 4(4):580-82.

Klimley AP. The determinants of sexual segregation in the scalloped hammerhead shark, Sphyrna lewini. Environ Biol Fish. 1987; 18(1):27-40.

Koob TJ, Cox DL. Introduction and oxidation of catechols during the formation of the skate (Raja erinacea) egg capsule. J Mar Biol Assoc UK.1990; 70(2):395-411.

Kyne PM, Simpfendorfer CA. Deepwater chondrichthyans. In: Carrier JC, Musick JA, Heithaus MR, editors. Sharks and their relatives II: Biodiversity, adaptive physiology and conservation, Boca Raton: CRC Press; 2010. p.37-113.

Lorenzen K. Toward a new paradigm for growth modeling in fisheries stock assessments: embracing plasticity and its consequences. Fish Res. 2016; 180:4-22.

Lucas AJ, Guerrero RA, Mianzán HW, Acha EM, Lasta CA. Coastal oceanographic regimes of the Northern Argentine Continental Shelf (34-43 ${ }^{\circ}$ S). Estuarine, Coastal Shelf Sci. 2005; 65(3):405-20.

Luer CA, Walsh CJ, Bodine AB, Wyffels JT. Normal embryonic development in the clearnose skate, Raja eglanteria, with experimental observations on artificial insemination. Environ Biol Fishes. 2007; 80:239-55.

Mabragaña E, Figueroa DE, Scenna LB, Díaz de Astarloa JM, Colonello JH, Delpiani G. Chondrichthyan egg cases from the south-west Atlantic Ocean. J Fish Biol. 2011; 79(5):1261-90.

Mabragaña E, Lucifora LO, Corbo ML, Díaz de Astarloa JM. Seasonal reproductive biology of the bignose fanskate Sympterygia acuta (Chondrichthyes, Rajidae). Estuaries Coast. 2015; 38(5):1466-76.

Mabragaña E, Lucifora LO, Massa AM. The reproductive ecology and abundance of Sympterygia bonapartii endemic to the south-west Atlantic. J Fish Biol. 2002; 60(4):951-67.

Massa A, Lamilla J. Sympterygia bonapartii. The IUCN Red List of Threatened Species 2004: e.T44597A10912987. http://dx.doi. org/10.2305/IUCN.UK.2004.RLTS.T44597A10912987.en. Downloaded on 08 August 2018

Massa AM, Lucifora LO, Hozbor NM. Condrictios de la región costera bonaerense y uruguaya. In: Sánchez RP, Bezzi SI, editors. El Mar Argentino y sus recursos pesqueros. Los peces marinos de interés pesquero. Caracterización biológica y evaluación del estado de explotación. Instituto Nacional de Investigación y Desarrollo Pesquero. Vol. 4. Mar del Plata: INIDEP; 2004. p.85-100.

Menni- RC, Stehmann MFW. Distribution, environment and biology of batoid fishes off Argentina, Uruguay and Brazil: a review. Rev Mus Argentino Cienc Nat. 2000; 2(1):69-109.

Mohan PJ, Clark ST, Schmid TH. Age and growth of captive sharks. In: Smith M, Warmolts D, Thoney D, Hueter R, editors. Elasmobranch husbandry manual: captive care of sharks, rays, and their relatives. Columbus: Ohio Biological Survey Inc; 2004. p.201-226.

Moya AC, Andrade MC, Galíndez EJ. Morphology and dynamics of male gametogenesis in Sympterygia bonapartii (Chondrichthyes, Rajidae) from Northern Patagonia. Iheringia Ser Zool. 2015; 105(3):316-24.
Murru FL. The care and maintenance of elasmobranchs in controlled environments. In: Pratt HL, Gruber SH, Taniuchi $\mathrm{T}$, editors. Elasmobranchs as living resources: advances in the biology, ecology, systematics, and the status of the fisheries. NOAA Technical Report NMFS 90; 1990. p.203-209.

Natanson LJ, Gervelis BJ, Winton MV, Hamady LL, Gulak SJB, Carlson JK. Validated age and growth estimates for Carcharhinus obscurus in the northwestern Atlantic Ocean, with pre- and post management growth comparisons. Environ Biol Fish. 2014; 97(8):881-96.

Natanson LJ, Skomal GB, Hoffmann SL, Porter ME, Goldman KJ, Serra D. Age and growth of sharks: do vertebral band pairs record age? Mar Freshwater Res. 2018; 69(9):1440-52.

Neer JA, Rose KA, Cortés E. Simulating the effects of temperature on individual and population growth of Rhinoptera bonasus: a coupled bioenergetics and matrix modeling approach. Mar Ecol Prog Ser. 2007; 329:211-23.

Oddone MC, Velasco G. Size at maturity of the smallnose fanskate Sympterygia bonapartii (Müller \& Henle, 1841) (Pisces, Elasmobranchii, Rajidae) in the SW Atlantic. ICES J Mar Sci. 2004; 61(2):293-96.

Oddone MC, Vooren CM. Comparative morphology and identification of egg capsules of skate species of the genera Atlantoraja Menni, 1972, Rioraja Whitley, 1939 and Sympterygia Müller \& Henle, 1837. Arq Cienc Mar. 2008; 41(2):5-13.

Palm BD, Koester DM, Driggers WB, Sulikowski JA. Seasonal variation in fecundity, egg case viability, gestation, and neonate size for little skates, Leucoraja erinacea, in the Gulf of Maine. Environ Biol Fish. 2011; 92(4):585-89.

Perier R, Estalles M, Coller M, Di Giacomo EE. Reproductive biology of the endemic skate Psammobatis lentiginosa in the San Matías Gulf (south-western Atlantic). J Mar Biol Assoc UK. 2011; 91(6):1165-73.

Pinheiro JC, Bates D. Mixed-effects models in S and S-plus. New York: Springer; 2000.

Pinheiro J, Bates D, DebRoy S, Sarkar D.D, R Core Team. 2014. nlme: Linear and nonlinear mixed effects models. R package version 3.1-117. http://CRAN.R-project.org/package=nlme.

Pratt HL, Casey JG. Shark reproductive strategies as a limiting factor in directed fisheries, with a review of Holden's method of estimating growth parameters. In: Pratt HL, Gruber SH, Taniuchi T, editors. Elasmobranchs as living resources: advances in the biology, ecology, systematics, and the status of the fisheries. NOAA Technical Report NMFS 90; 1990. p.97-110.

R Core Team. R: A language and environment for statistical computing. The R Foundation for Statistical Computing, R version 3.1.1. Vienna, .2014. http://www.r-project.org.

Rose KA, Cowan JH, Winemiller KO, Myers RA, Hilborn R. Compensatory density dependence in fish populations: importance, controversy, understanding and prognosis. Fish Fish. 2001; 2(4):293-327.

Serra-Pereira B, Figueiredo I, Bordalo-Machado P, Farias I, Moura T, Gordo LS. Description of Portuguese mixed-fisheries with positive landings of Raja brachyura Lafont, 1873 and Raja montagui Fowler, 1910. ICES CM Documents. 2005; 18:1-10. 
Serra-Pereira B, Figueiredo I, Gordo LS. Maturation, fecundity, and spawning strategy of the thornback ray, Raja clavata: do reproductive characteristics vary regionally? Mar Biol. 2011; 158:2187-97.

Sibly RM, Baker J, Grady JM, Luna SM, Kodric-Brown A, Venditti C, Brown JH. Fundamental insights into ontogenetic growth from theory and fish. Proc Natl Acad Sci USA. 2015; 12(45):13934-39.

Smart JJ, Chin A, Tobin AJ, Simpfendorfer CA. Multimodel approaches in shark and ray growth studies: strengths, weaknesses and the future. Fish Fish. 2016; 17(4):955-71.

Sminkey TR, Musick JA. Age and growth of the sandbar shark, Carcharhinus plumbeus, before and after population depletion. Copeia 1995; 1995(4):871-83.

Smith MFL. Capture and transportation of elasmobranchs, with emphasis on the grey nurse shark (Carcharias taurus Rafinesque, 1810). Aust J Mar Freshwater Res. 1992; 43(1):325-43.

Smith M, Warmolts D, Thoney D, Hueter R. Elasmobranch husbandry manual: captive care of sharks, rays and their relatives. Columbus: Ohio Biological Survey Inc.; 2004.

Stamps J, Krishnan VV. Sexual bimaturation and sexual size dimorphism in animals with asymptotic growth after maturity. Evol Ecol. 1997; 11(1):21-39.

Stearns SC. The evolution of life histories. Oxford: Oxford University Press; 1992.

Tamini LL, Chiaramonte GE, Perez JE, Cappozzo HL. Batoids in a coastal trawl fishery of Argentina. Fish Res. 2006; 77(3):326-32.

Templeman W. Development, occurrence and characteristics of egg capsules of the thorny skate, Raja radiata, in the Northwest Atlantic. J Northw Atl Fish Sci 1982; 3(1):47-56.

Thorson TB, Langhammer JK, Oetinger MI. Reproduction and development of the South American freshwater stingrays, Potamotrygon circularis and P. motoro. Environ Biol Fish. 1983; 9(1):3-24.

Uchida S, Toda M, Kamei Y. Reproduction of elasmobranchs in captivity. In: Pratt HL, Gruber SH, Taniuchi T, editors.
Elasmobranchs as living resources: advances in the biology, ecology, systematics, and the status of the fisheries. NOAA Technical Report NMFS 90; 1990. p.211-238.

Walker PA, Hislop JRG. Sensitive skates or resilient rays? Spatial and temporal shifts in ray species composition in the central and north-western North Sea between 1930 and the present day. ICES J Mar Sci. 1998; 55(3):392-402.

Willson K, Smith M. Reproduction of the sand tiger shark, Carcharias taurus (Rafinesque, 1810), at UnderWater World SEA LIFE Mooloolaba from 1992-2012. In: Smith M, Warmolts D, Thoney D, Hueter R, Murray M, Ezcurra J, editors. The elasmobranch husbandry manual II: recent advances in the care of sharks, rays and their relatives. Columbus: Ohio Biological Survey Inc.; 2017. p.391-401.

Winemiller KO, Rose KA. Patterns of life-history diversification in North American fishes: implications for population regulation. Can J Fish Aquat Sci. 1992; 49(10): 2196-218.

Wearmouth VJ, Southall EJ, Morritt D, Thompson RC, Cuthill IC, Partridge JC, Sims DW. Year-round sexual harassment as a behavioral mediator of vertebrate population dynamics. Ecol Monog. 2012; 82(3):351-66.

Wourms JP, Grove BD, Lombardi J. The maternal-embryonic relationship in viviparous fishes. In: Hoar WS, Randall DJ, editors. The physiology of developing fish: viviparity and posthatching juveniles. San Diego: Academic Press; 1988. (Fish Physiology; 11) p.1-134.

Wyffels JT. Embryonic development of chondrichthyan fishes - a review.In: Kunz YW, Luer CA, Kapoor BG, editors. Development of non-teleost fishes. Enfield: Science Publishers; 2009. p.1-103. 
